\title{
2. The Etymology of the name BāBar.
}

$B \bar{a} b a r$ appears to be a lengthened form of the word , babar or bibar, and is commonly explained as meaning 'tiger.' In our Persian and Hindustānī dictionaries the word بر is rendered both as 'lion' and as 'tiger'; while Lane, in his Arabic dictionary, gives as one explanation of the word, "a certain Indian animal, stronger than the lion, between which and the lion and leopard, or panther, exists hostility." He also says that the word is foreign, or Persian. The word occurs several times in Jahāngīr's Memoirs, and in one place, B.M. MS. Add. 26,215, p. 245a, he distinguishes it from the شئر sher or tiger, and speaks of having had both these dissected in order to find the cause of their courage. It seems to me that he understood the word as meaning 'leopard,' and as he speaks on more than one occasion of having despatched the babar by a single shot, it probably was a smaller animal than the tiger. In one place in Afghanistan, either Bābar's tomb or the entrance of the inscription-cave described by Darmesteter, two leopards are sculptured, which seems to show that $B \bar{a} b a r$ was supposed to mean 'leopard.' In Zend the word is bawri, and in Balfour's Cyclopaedia and Jerdon's "Mammals of India," p. 99, the form bibla is given. Is not, then, the word the

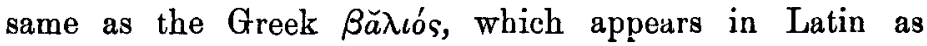
varius, and means 'the spotted'? In Anglo-Indian slang the leopard and the tiger are commonly distinguished as "spots and stripes." The word may also be connected with the Greek pardos or pardalis.

May 5, 1900.

H. Beveridge.

3. Pahlavi words, derivation and sianificance.

Bombay.

May 3, 1900.

Dear Sir,-With reference to the Pahlavi words akhtman (akhtâ) and nishman (nîshâ) as they are used in passages such as the following, I submit for the criticism of the members 
of the Royal Asiatic Society a brief note suggestive of their special siguifications in the respective quotations given below.

These Pahlavi passages, which occur in (1) $Y \hat{a} d g a \hat{r}-\hat{\imath}-$

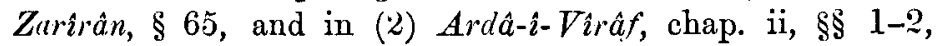
run thus:-

(1) "Va âkhar yemalelunîd Kâ̂-Vishtâsp-Shah â̂gh hat hamâk ben $\hat{a}$ va akh va vispûhragân î li, Kai-Vishtâsp-Shah, va zakich î Hûtôs, zyam akht $\hat{a}$ va nîsh $\hat{a}$, mûn min bena $\operatorname{vad} \operatorname{bent} \hat{a} 30$ azash zâd yekavîmûnêd, hamâk yemîlûnt yehevûnd; adînam denâ avîzak Dîn î̀ Mâzdaiasnân chîgûnam min Aûharmazd mekablûut barâ lâ shedkûnam."

(2) "Va ôl $\hat{a}$ Vîrâf râî 7 akht $\hat{a}$ yehevûnd, va ôlâshân kôlâ 7 akhtâân Vîrâf chîgûn nîshẩ yehevûnt hûmand."

The translators hitherto of these citations have, in their interpretations, attached to the two words akhtâ and nîshâ the ordinary meanings of 'sister' and 'wife' in which they are generally used in Pahlavi. But I believe that these two words have distinct readings and significations in the texts above-mentioned. The decipherment in the first case is not zyam akhtâ va nîshâ, "who is my sister and wife," but zyan khajî̀ mûn nîshâ. Here the two words khajîd and mûn are joined together in the original text by an ignorant copyist to form the commonly known word akhtman, which means ' sister.'

In the first passage the word alktman in the text is properly khajid plus mûn (the latter can also be read man, a pronoun sometimes used in Pahlavi as the Pazend synonym of the Huzvaresh $(i)$.

'The word khajîd is derived from the Avesta hva, 'self' (Skt. sva), and chi (Skt. chi), 'to choose.' Literally, it means 'chosen by one's self.' It is identical with the modern Persian khazidan or khûzidan, which signifies 'to invite to marriage' or 'to solicit for the hand of a maiden.' 1 Hence my version of the Pahlavi text (1) is :-

1 See under the word, Maulawi Fazl-i-Ali's Dictionary, p. 237. 
"And afterwards the king $K a i-V_{i s h}$ âsp spoke thus:- If all the sons, and brothers, and princes of mine, (who am) Kat Vishtâsp Shah, and of $H \hat{u} t \hat{s} s$, who was chosen by myself (to be my spouse), (and) who (was married to me and) is my wife, and by whom are begotten 30 , including sons and daughters; (if they) are to die together, then (too) I shall not forsake this sacred Mazdayasnian Revelation such as I have accepted from Aûharmazd." "

The Pahlavi expression syam khajid suggests to us that the courting or solicitation for the hand of a maiden was not unknown to the Irânians in the age of the Avesta. The failure of such a solicitation does not seem to have been uncommon, as the highest power, like King Vishtâsp, emphatically expresses the successful result of his courtship in his subsequent connubial union with Hûtôs.

In the second Pahlavi passage quoted above, the word nîshâ is not used in its ordinary import of 'wife' or 'woman,' but it seems to be, as in other Pahlavi MSS., an erroneous reading of the original nismô or nisman, which means 'soul,' ' life,' ' vital power,' etc. (cf. S.B.E., vol. xxxvii, chap. xiv, $\$ 1$ ). This much discussed passage can therefore be rendered: "Vîrâf had seven sisters, and all these seven were unto Vîrâf as dear as (his) soul."

A further progress in the decipherment and interpretation of more Pahlavi texts will, I hope, enable us to throw better light on such ambiguous and obscure Pahlavi words and expressions.-Yours sincerely,

\section{Darab Dastur Peshotan Sanjana.}

\section{Santak or Sign-Signatures in India.}

Sir,-Perhaps some of the readers of your Journal may kindly help me to obtain further information as to the origin of the santaks or marks used to attest the signatures of illiterate persons in some parts of India, and as to the use of similar marks in other countries. 